\title{
Grasberg block cave mine rail project update - PT Freeport Indonesia
}

\author{
F Lara Moran Freeport-McMoRan Inc., United States
}

C Brannon Freeport-McMoRan Inc., United States

A Hariyadi PT Freeport Indonesia, Indonesia

M Castro PT Freeport Indonesia, Indonesia

J Gillman PT Freeport Indonesia, Indonesia

\begin{abstract}
The Grasberg Block Cave (GBC) mine has implemented an automated train ore haulage system for transporting production ore from multiple chute galleries to the underground crushers. This paper provides an update of the current operations; commissioning activities and rail expansion plans during production ramp up; an overview of lessons learned during the rail commissioning; and expected operational challenges. The key to the success of the GBC rail haulage system is to manage all of these challenges in an efficient way so that the production targets can ultimately be achieved. The GBC rail haulage design comprises approximately $23 \mathrm{~km}$ of rail (comprising sections of both ballasted and embedded track) and 117 chutes to load ore to the ore cars and deliver the ore to three unloading stations above the crushingconveying system. Currently, 26 chutes are operating and 8 are under construction or on commissioning phase. Ore is currently being delivered to one operating unloading station, while a second station will be commissioned in 2021. The rail system is designed to operate in full-automated mode, including chute selection, loading, hauling and dumping. Chute loading operation is done remotely from the surface control room. Trains consist of 11 bottom-dump $20 \mathrm{~m}^{3}$ ore cars driven by a 40-tonne driverless electric locomotive. Approximately 10 to 12 trains and one spare train are required to maintain full production. To date, three trains are available on site for the current mine operations and control systems commissioning. The GBC rail project has been divided into five stages based on the current production schedule. Current development and construction activities are focused on finalizing the required haulage infrastructure during the early years of production. At the same time, detailed engineering and procurement of long lead-time items are progressing to ensure that the production ramp up at GBC is not at risk due to a delayed rail haulage system. Stages 2 and 3 of the rail system are expected to be commissioned by 2020, followed by stage 4 in 2021/2022.
\end{abstract}

\section{Introduction}

This paper provides an update of the current haulage operations and commissioning activities in GBC; a description of the rail expansion plans developed to manage the complexities of the rail project during the production ramp up; an overview of lessons learned during the rail construction and commissioning; and a description of the expected operational challenges and risks acknowledged and continuously managed by PTFI during the development of the GBC rail haulage project.

The Grasberg Block Cave (GBC) rail haulage project at PT Freeport Indonesia (PTFI) is located in the Grasberg Mining District in the province of Papua, Indonesia. PTFI is expected to be producing a peak of approximate 240,000 tpd from four underground mines: GBC, the Deep Mine Level Zone (DMLZ) block cave mine, Big Gossan open stope mine and the future planned project Kucing Liar block cave mine (KL). 
Currently, PTFI forecasts that the GBC mine, which began production in early 2019 , is expected to ramp up to 130,000 to 160,000 tpd by 2026 . The automated train ore haulage system has been designed to transport up to 160,000 tpd to manage the full production rate.

The GBC haulage level is located at 2,760 $\mathrm{m}$ above sea level, $70 \mathrm{~m}$ below the mine extraction level. The main objective of the GBC automated train ore haulage system is to transport the material stored in ore and chute passes from multiple chute galleries to the three unloading stations located above the ore bins and underground crushers. Each train consists of 11 bottom-dump Nordic Minesteel Technologies (NMT) ore cars of $20 \mathrm{~m}^{3}$ capacity and are driven by a 40-tonne driverless electric Schalke locomotive. PTFI estimates that approximately 10 to 12 trains and one spare train are required to maintain full production.

The GBC automated train ore haulage system is divided into five production tracks with a total of 20 chute galleries, three unloading stations for three underground crushers, and a maintenance and offices area (Figure 1). The GBC rail haulage operation will have $23 \mathrm{~km}$ of rail when fully installed (comprising sections of ballasted track on the main lines and embedded track in the chute galleries, unloading stations, and shop areas). The standard rail track being installed is a 1,435 mm gauge with AS60 steel. PTFI is working on modifying the standard 1,435 $\mathrm{mm}$ gauge to $1,445 \mathrm{~mm}$ gauge in the sections of curved rail.

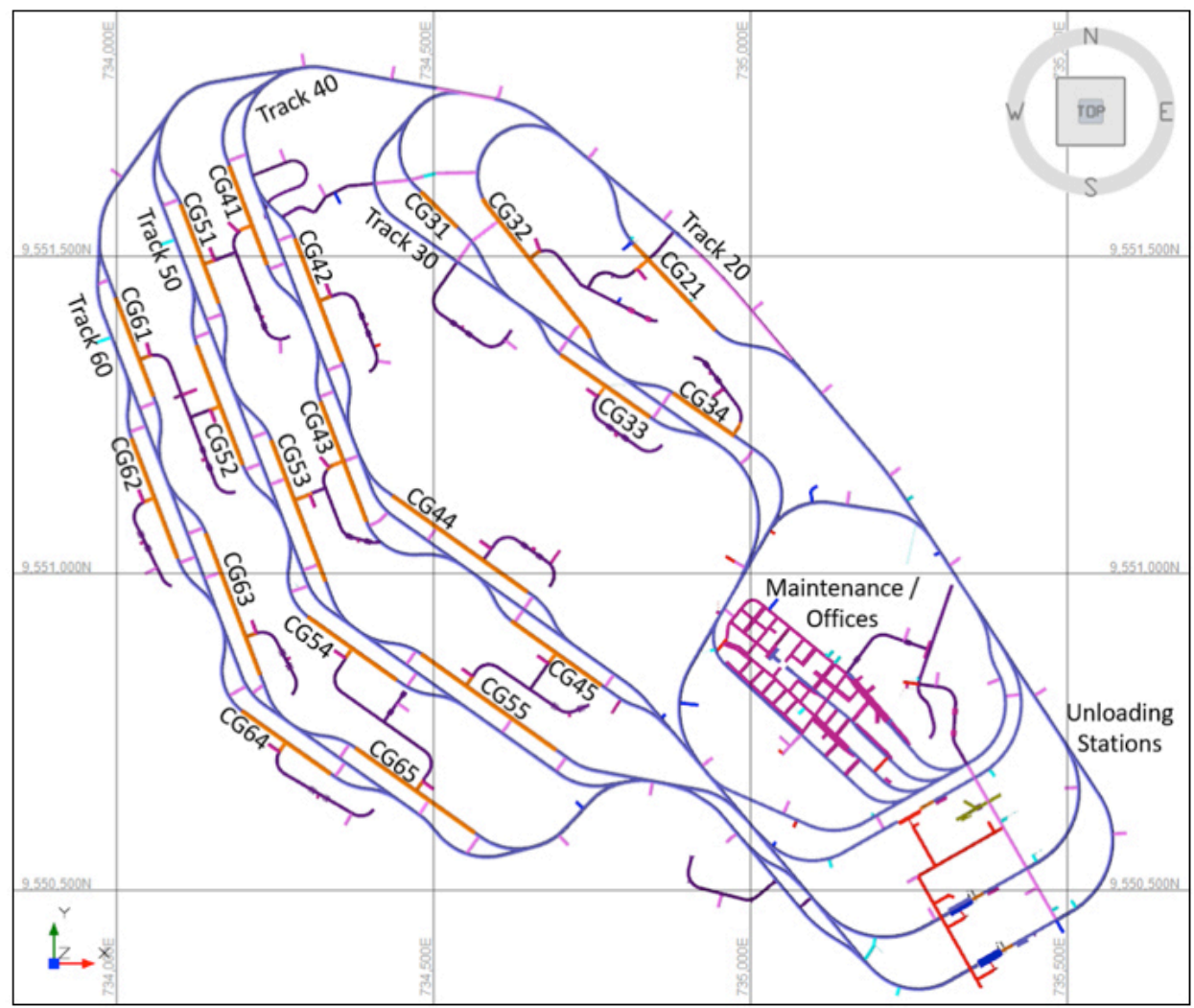

Figure 1 GBC haulage level life-of-mine plan view layout

\section{Train operations description}

This section provides a summary description of the current condition of the train haulage operations in PTFI. More detailed descriptions of the designs and train controls involved in the GBC rail project have been provided in previous conferences (Hariyadi et al. 2016; Pascoe et al. 2016). Minor changes have occurred in the mine design since 2016, primarily driven by increased levels of knowledge of the geotechnical of the rock mass; these include larger pillars between the chute galleries and main track lines, and two cases of chute gallery orientation adjustments. Unlike previous publications, this paper aims to drive attention to the lessons learned, challenges and risks, and project management during construction and production ramp up of GBC. 


\section{$2.1 \quad$ Loading}

Loading of the ore cars occurs from one or more chutes that are aligned into chute galleries located on the haulage level. A total of 117 chutes will be installed during the duration of the mine life. Loading is remotely controlled by an operator in the train controls centre, which is located on the surface in the underground mining office building. The chute operator views the chute loading area via cameras and takes control of the train driving it through the chute gallery. When the first ore car approaches the destination chute, the operator starts controlling the chute and also the train speed in order to load approximately 300 tonnes of ore per train. These chutes are hydraulically controlled.

After the train is loaded and is leaving the chute, the level of the ore in each car is checked by a lightbased sensor to check overloading or the loading of unsafe materials that might interfere with the Overhead Catenary System (OCS) or other infrastructure. If this sensor is activated, the chute operator is notified giving him the opportunity to stop the train and then maneuver it through the loading chute in order to correct the high load using the lowered chute lip.

Additionally, there is an extra profile detector before leaving the chute gallery that stops the train in case of detecting high material extending out of the ore car. If that is the case, the removal of the undesirable object usually requires manual intervention before resuming the train operation.

\subsection{Train controls}

After loading is finished and the train profile is checked, the locomotive engages to the OCS and receives movement authority to the selected unloading station. The PTFI rail project is a highly automated system that is designed to operate in remote mode only when loading ore in the chute gallery. The process of destination selection, driving and dumping is done in fully automated mode.

PTFI's rail system is monitored and controlled by the INTERFLO 150 system provided by Bombardier as an integrated part of the distributed control system (DCS) solution provided by Midroc Automation. INTERFLO 150 was chosen as it is a well-established product in underground mining operations with a train system. This system is currently successfully operated in the Kiruna Mine in Sweden, and also at the El Teniente Mine in Chile.

The train control system is designed to maximise production while maintaining a maximum safety standard controlled by the Automatic Train Protection Onboard System (AOS). The INTERFLO system communicates with the AOS to determine speeds, control train direction and assign destinations. The Automatic Train Protection (ATP) system, which is part of the AOS, defines a rolling movement authority zone, which spaces out trains dynamically based on speeds, estimated braking distances, rail design, tonnages and other parameters. The system can detect the train locations and speeds through the installation of a series of passive balises, which act like proximity tag switches. The balises are read by microwave frequency systems as the train passes over them. The communications between the system and the locomotives is by a redundant wireless local area network (WLAN) Wi-Fi systems to maintain total track coverage.

\subsection{Unloading}

After a train departs from the chute gallery where it is loaded, it receives a command from the INTERFLOATP system to travel to one of three unloading stations. The unloading process is automatic, using a bottom dump system designed and supplied by NMT (Nordic Mine Technologies). NMT is also the provider of the ore cars used in the PTFI Rail System, the chute designs and the design and supply of the unloading stations.

Before entering the station, the train passes over a weigh station where it records its loaded weight. There is a common weigh scale on the exit track that measures the unloaded weight. The overall control system monitoring the trains calculates the train discharged loads. 
When the train enters the unloading station, it disengages from the OCS and slows to $2.5 \mathrm{~km} / \mathrm{h}$. As the train engages into the propulsion units, the locomotive switches off its traction power.

The propulsion system pulls the train over the ore bin. The train is supported on rollers over the bin as the bottom discharge cars empty guided by the camelback profile. The second propulsion set counteracts the surge caused by the discharge to maintain a constant speed and pulls the end of the train out of the unloading station until the locomotive is able to again engage with the traction system. The variable frequency drives (VFDs) are equipped with discharge resisters to ensure smooth operation.

Upon exiting the unloading station propulsion units, the system hands over control back to the INTERFLO (Train Control) system. The train proceeds under battery power until ordered to engage its traction to the OCS. The INTERFLO then decides the next movement authority permissions and directs to the next chute for loading.

\section{Rail haulage status update}

Rail haulage operations began in early 2019 and by June 2020, averaged 32,000 tpd, with peak days of $40,000 \mathrm{tpd}$. Production ramp-up will continue through to full production. By the end of 2020, production haulage should be at 45,000 tpd and reach 130,000 tpd in 2023. The locomotive and ore car fleets will expand as required to meet the production targets. During peak production, there will be about 10 trains in operation.

Current GBC production is being handled by four trains and a single unloading station (US601). Due to the current chute availability and concurrent construction activities, one train has been set up with five cars, one with nine cars and two trains with eleven cars. The shorter trains are able to enter into shorter chute galleries that are partially commissioned. A total of 26 chutes have been commissioned in five chute galleries as of June 2020. Six more chutes are scheduled to be commissioned before the end of this year.

\subsection{Construction activities}

\subsubsection{Chute galleries}

A total of 26 chutes from five chute galleries are operational. This number will increase to 34 chutes with the 8 chutes that are currently under construction. Construction work is performed in sections of three or four chutes at a time. GBC construction crews have the ability to work on two chute gallery sections at the same time. One section of chutes takes approximately six months to be built. Figure 2 shows a chute gallery under construction.

Chute gallery construction is most efficient with two accesses. In order to facilitate the availability of working fronts and equipment installation, chute galleries can be accessed through the main rail tunnel or via a ramp that connects the service level with an area near the chute gallery centre point. The excavation of chute galleries begins from the access ramp.

\subsubsection{Unloading station}

Construction of the second unloading station started on October 2019. Unloading station construction is a complex process that is done in parallel with the underground crusher - conveyor complex construction below the unloading station. The crusher construction is the primary component of the critical path of the ore flow system. Based on current production ramp-up plans, the 602 unloading station-crusherconveyor system will be ready for wet commissioning on April 2021.

Each unloading station-crusher-conveyor system is able to handle an average of about 55,000 tpd. This ore flow capacity depends upon the ability of the rail haulage system to consistently deliver sufficient ore to each crusher. The ramp up to full production is thus dependant on the ability of the construction activities to deliver the crushers as well as the unloading stations and chute galleries on time. 


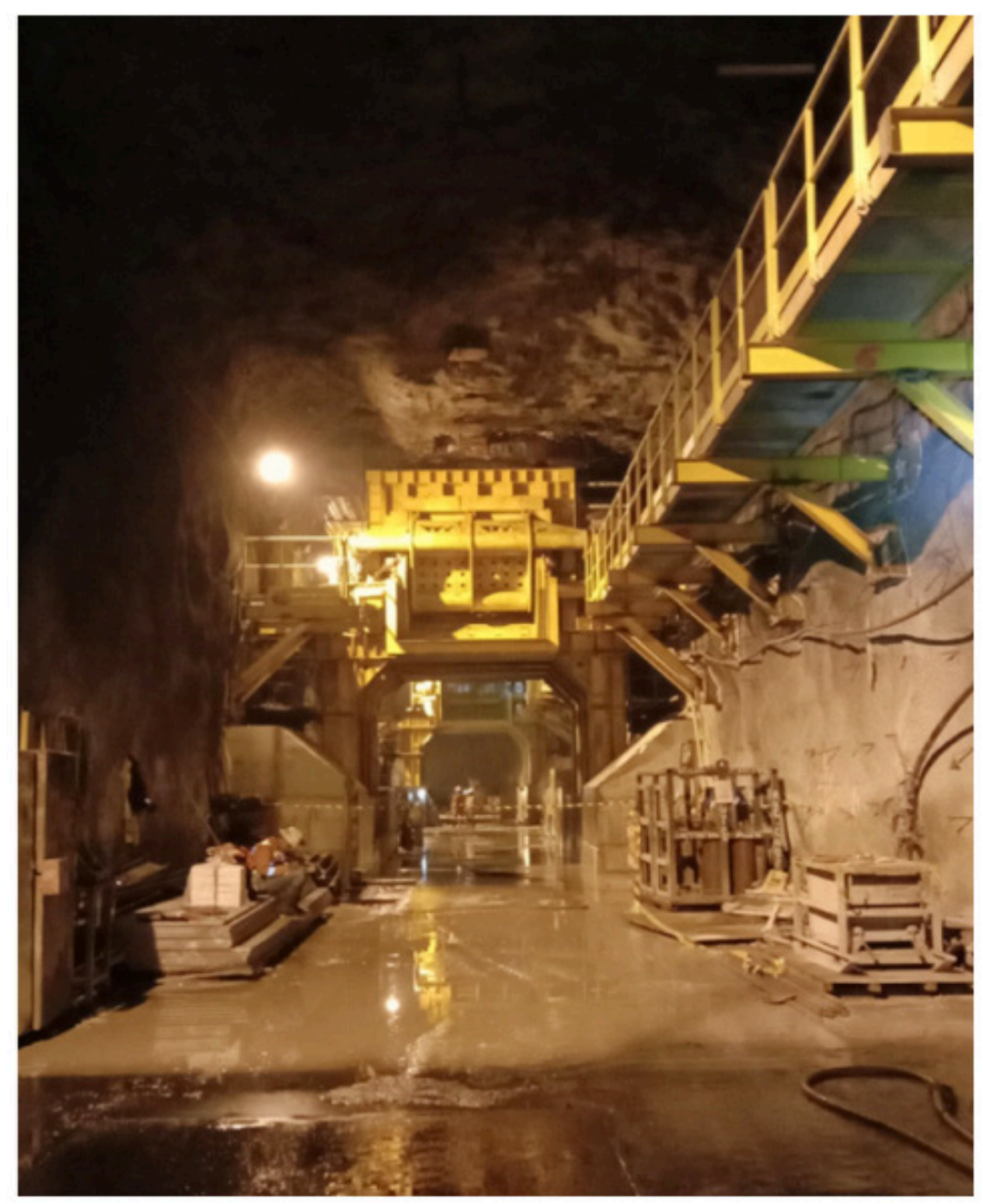

Figure 2 Chute gallery CG34 steel installation

\subsubsection{Rail track}

Rail track installation starts when a section of the tunnel is excavated and handed over to the rail construction crews. Figure 3 shows the currently installed rail sections in the system. The handover requires all permanent ground support to be fully installed. At times, a delay in the handover has been required when that section is still needed as an access for development or other construction activities.

Two types of track are being installed: i) concrete embedded track, and ii) ballasted track. Embedded track is installed in the rail haulage workshop, the unloading stations and chute galleries. All embedded track areas are reinforced for the passing of fully loaded trains, and sometimes-required rubber tire and foot traffic. Ballasted track is installed along the main tracks that access the chute galleries. The ballasted track installed is specified for a heavy-haul track structure for maximizing the durability of the track.

Nominal track gauge in straight track areas is $1,435 \mathrm{~mm}$ with up to $10 \mathrm{~mm}$ gauge widening. Sleepers are installed every $600 \mathrm{~mm}$. PTFI is currently working on improving rail life by installing wider sleepers in the curved sections of the rail track. Curved track gauge will be $1,445 \mathrm{~mm}$ with up to $10 \mathrm{~mm}$ gauge widening.

\subsubsection{Rail haulage workshop}

The rail haulage workshop is the primary location for component storage, routine rolling stock inspections and maintenance (Pascoe et al. 2016). The workshop area comprises the locomotive shop, cars shop, shaft access, trolley shop and other rail-related maintenance activities. Embedded track is installed anywhere train access is required to accommodate rubber tire and foot transit. 


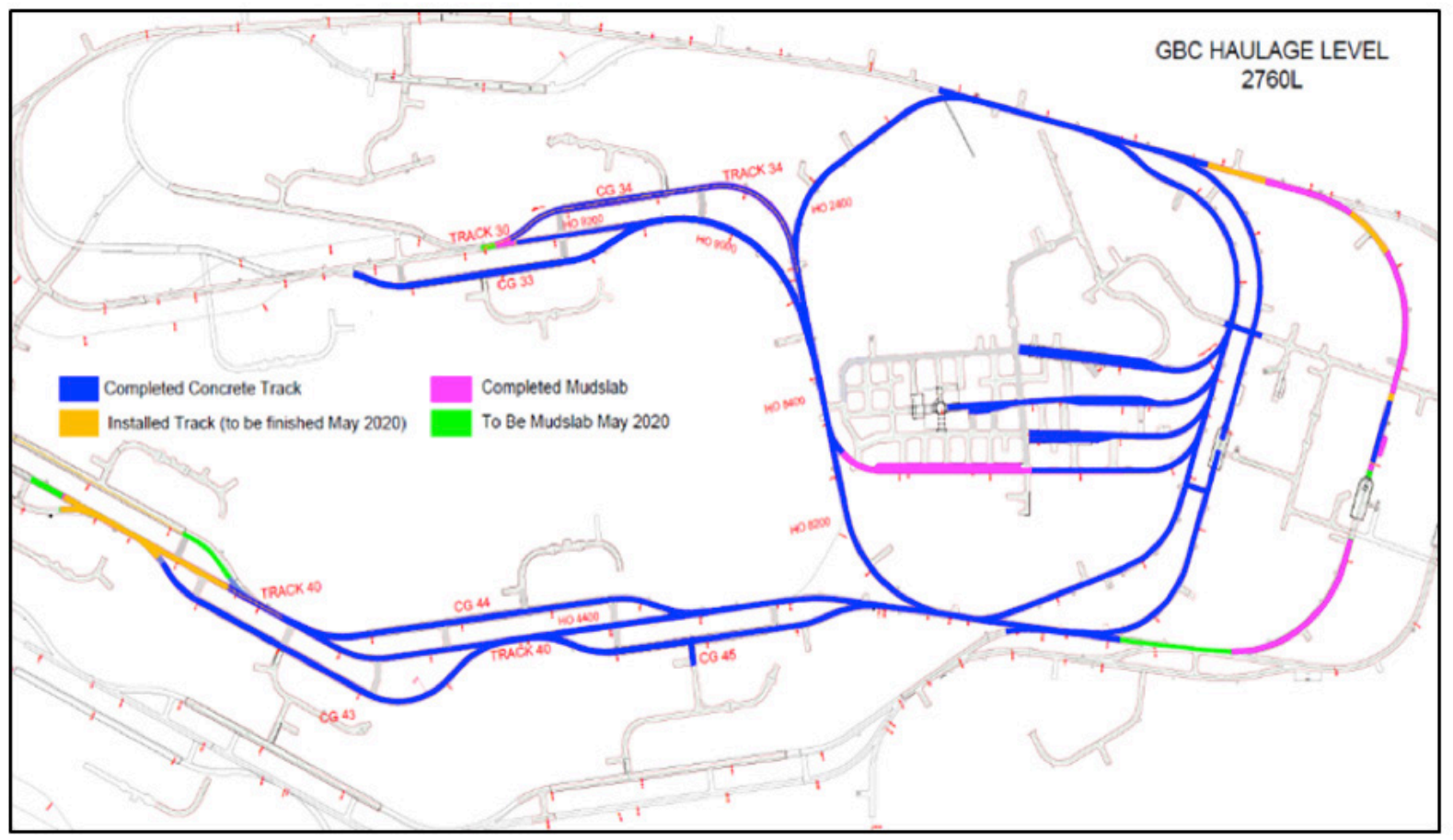

Figure 3 Rail track installed up to May 2020

As of June 2020, the majority of the rail shop has been constructed and is in operation, including the locomotive shop and ore car shop. Also in operation are the facilities for ancillary maintenance functions such as track repair, control room, OCS repair, chute maintenance, refuge chamber and warehousing.

\subsubsection{Signalling and automation}

Signalling and automation construction is divided into three main areas: i) chute galleries, ii) unloading stations, and iii) rail track. Signalling and automation construction activities for chute galleries and unloading station are performed in parallel to the infrastructure construction and comprise the installation of the closed-circuit television (CCTV) system, rock breakers and chutes controls, distribution panels, optical and wireless network, additional sensors and power systems.

Signalling and automation construction activities for rail track can be performed before or after the track is installed and includes the installation of all the trackside equipment such as balises, point machines, turnouts, derailers, derailment and profile detectors and weighing bridges.

After the equipment installation is finished, the system passes to the commissioning stage, when these sections are incorporated into the train controls system. Once commissioned, that section of track, chute gallery or unloading station are now a part of the automated control system and the area is opened to train traffic.

As of June 2020, five chute galleries were commissioned and one more is expected to be commissioned before the end of 2020 .

\subsubsection{Traction power}

The main supply of electricity to the locomotive is the OCS that hangs from the back of the tunnel. The OCS is installed after the track is ready and is required for commissioning of each segment of track for train traffic. Within the chute galleries, the unloading station and rail shop the locomotives disengage from the OCS and revert to battery power. 
As of November 2019, there is one traction supply station (TSS) energized, hence TSS1 is the only supply of power to the OCS. In order to provide power redundancy for the train operations, a second TSS was energized in November 2019. A third TSS will be required to provide redundancy in the loop areas since circuit distances are longer, generating a voltage drop that puts at risk the 24/7 operations in case of a failure.

\subsection{Commissioning activities}

GBC rail project commissioning aims to ensure that the rail system is functioning in a safe manner and that all technical and project requirements are met. Commissioning procedures focus on integrating and closing the interfaces between different systems from different third parties and PTFI. Every component added to the rail haulage system has to pass a factory acceptance/inspection test (FAT), a site installation test, a site acceptance test and a site integration test.

The FAT is performed during production in the factory when it is confirmed that the components or the equipment behaves according to the design and project requirement previously specified. An example of this stage is the reception of mine load centres (MLCs) in the provider factory where a set of tests are performed in order to ensure that the MLC to be shipped does what is meant to do.

The site installation test is performed following the installation of equipment and aims to ensure that the components are correctly installed and wired. At this stage, equipment is checked and deemed suitable for operation. An example of this stage is the functioning tests of chute gallery components before opening the chute pass for production.

The site acceptance test is a series of activities aiming to prove that the equipment not only is well installed or well built, but also will perform in the operational environment in a safe manner, complying with all the design and project specifications. An example of this stage are the tests performed by Bombardier for the safe operation of trains under the automated system criteria. Train setups (11-cars) must pass several safe braking performance and train stopping ability tests that ensure that the train will stop safely within the specifications under any possible circumstance.

The site integration test is the stage when the equipment is put in operation with all the systems and sub-systems already implemented. At this stage, the rail haulage system components are approved to work under the specifications defined in the site acceptance test. Meanwhile, third parties and PTFI maintain a close look into the daily train operations. Third parties in the GBC rail haulage project include Midroc Automation, NMT, Bombardier, Siemens and Schneider. This stage focuses on integration testing of communication systems; communications with the remote operations facility; signalling systems and wayside equipment; driving trains at the appropriate speed for the segment of rail; and train acceleration and deceleration within specifications. The GBC rail project is now successfully running 24/7.

\section{$4 \quad$ Rail expansion plans}

GBC production planning forecasts that $\mathrm{GBC}$ rail haulage will be required to transport about 45,000 tpd by the end of 2020 and will reach 130,000 tpd during 2023. This intensive ramp-up requires that production and construction activities are well coordinated.

Based on the current GBC caving sequence, five additional chute galleries and the corresponding rail layouts and infrastructure are required to be commissioned before the end of 2023. A schedule of the future engineering, procurement, construction and commissioning (EPCC) activities has been developed based on the current production plans, which deliver the chute galleries required by production dates. This schedule defines the strategy required to achieve the critical commissioning dates to continue the GBC production ramp-up. Delays to these commissioning dates will put the production ramp-up at risk. The ongoing expansion plans of the rail haulage system are required to support and sustain the production ramp-up as the production areas expand. 
The expansion plans of the GBC rail system are driven by the development/production plan. A comprehensive plan and schedule have been developed for the expansion of the rail system, including design engineering, procurement and installation. The approved haulage level life-of-mine (LOM) design as well as the as-builts as of June 2020 (in red) are shown in Figure 4.

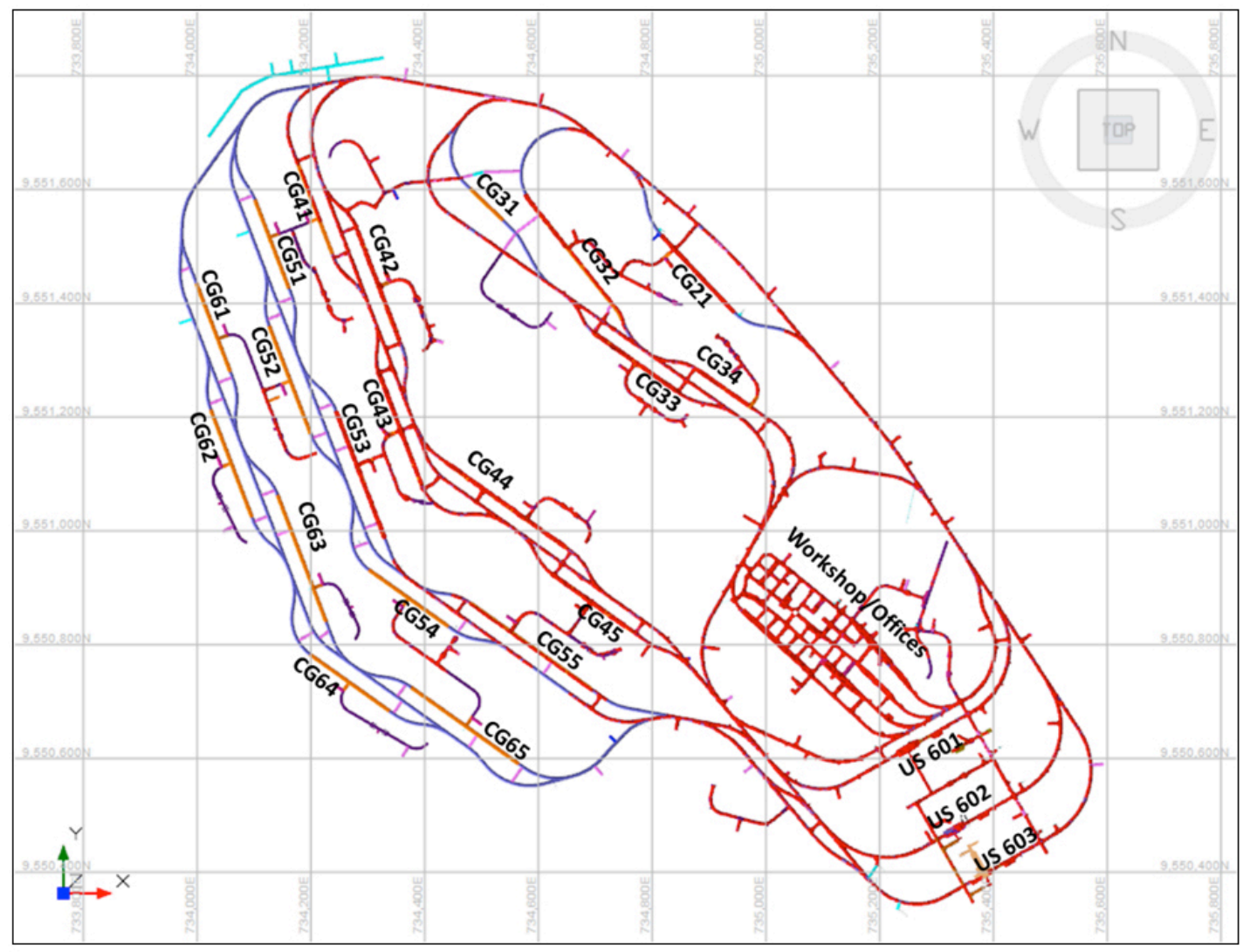

\section{Figure 4 GBC haulage level, LOM and as-builts}

PTFI has planned the rail project construction in five stages life-of-mine that are driven by the planned caving sequence in the various production blocks. The scope of each stage considers all of the engineering, procurement, construction and commissioning of chute galleries, unloading stations, traction power substations (TSS), track installation and train controls.

Over time, the scope within the individual stages has gone through numerous adjustments, primarily in response to changes to the caving sequence plans and overall schedule adjustments. In addition, the alignment of the rail lines and chute galleries have experienced a number of adjustments that were required due to updated rock quality information (moving chute galleries out of poor ground conditions for example). In addition, the modeled response of the reaction of the advancing cave to the haulage level infrastructure also identified potential issues with excessive cave stress conditions that required further adjustments to the rail layout designs.

The stage 1 of the GBC rail system is essentially complete, initially comprising 18 loading chutes in three chute galleries (CG33, CG44 and CG45), the unloading station 601, the rail workshop area, the rectifier substation TSS1 and the central control system. These three chute galleries are in the initial production areas and focused on the infrastructure and areas that were required to start the GBC caving production. Chute Galleries 34 and 43, and Rectifier TSS2 were added into stage 1 later in the process to react to the rapid expansion of the extraction level production areas.

Based on a better knowledge of the geotechnical characteristics of the deposit and the ability to produce more accurate caving expansion plans and development schedules, the initial stages planned for the GBC rail project construction stages 2 and 3 have been adjusted to tie to current schedules. Production sequences have changed since the initial construction schedule was produced. Therefore, the order of priority for the construction of chute galleries have been updated accordingly. 
The next two stages of work to be completed now use the terms "Stage 2-3 Initial Scope" and "Stage 2-3 Subsequent Scope", which reflects the fact that each of these scopes of work have parts of the original Stages 2 and 3 in the revised plan. Current engineering and procurement efforts have also been scheduled sequentially in order to optimize the utilization of resources internally and from PTFI providers. The scope of work considers the multi-disciplinary engineering and long-lead items procurement for the activities shown in Table 1.

Table $1 \quad$ GBC rail project planned scope of work

\begin{tabular}{|c|c|}
\hline Project stages & Tasks \\
\hline \multirow[t]{5}{*}{ Stage 2-3 Initial Scope } & Chute galleries 42,21 , and 32 \\
\hline & Train controls for CG21, CG32, CG42, and tracks MRT20 and MRT30 \\
\hline & Overhead catenary system (OCS) for the scope of work \\
\hline & Rectifier TSS2 relocation engineering updates \\
\hline & Rectifier TSS3 \\
\hline \multirow[t]{4}{*}{ Stage 2-3 Subsequent Scope } & Unloading station 602 \\
\hline & Chute galleries 52 and 53 \\
\hline & $\begin{array}{l}\text { Train controls and wayside equipment for CG52, CG53, US602 and } \\
\text { track MRT40 }\end{array}$ \\
\hline & Overhead catenary system (OCS) for the scope of work \\
\hline Project stages & Tasks \\
\hline \multirow[t]{4}{*}{ Stage 4 Scope } & Chute galleries $31,54,55,41$, and 51 \\
\hline & Unloading station 603 \\
\hline & $\begin{array}{l}\text { Train controls and wayside equipment for CG31, CG54, CG55, CG41, } \\
\text { CG51, US602, and tracks MRT50 and MRT60 }\end{array}$ \\
\hline & Overhead catenary system (OCS) for the scope of work \\
\hline Stage 5 Scope & Track 60 and all chute galleries on that rail line \\
\hline
\end{tabular}

Long lead times for engineering and procurement, followed by construction durations, dictate that component procurement must be initiated about 1.5 years in advance of the required commissioning dates. The intent of this plan is to ensure that the production ramp-up at $G B C$ is not at risk due to a delayed rail haulage system. The estimate duration of this scope will be two to three years with stage 2-3 being installed and commissioned by 2020 followed by stage 4 in 2021/2022.

Midroc-Bombardier provides the designs for all train control- and OCS-related facilities, including the types and quantities of the various power and communication cables required to support those facilities. However, those designs do not include the actual locations and routing of the system cabling. Therefore, in parallel with the Midroc-Bombardier design process, Stantec Engineering has been contracted to provide the designs required for the installation of the system, including:

- Locations of all control infrastructure along the rail lines and in the chute galleries

- Cable routing for train controls, communications, and power for all rail-related control facilities and wayside equipment

- Civil designs for the chute galleries and chute gallery control e-house locations 


\section{$5 \quad$ Challenges and risks}

\subsection{Procurement}

Equipment sourcing and delivery is one of the major challenges for the project. The unique characteristics of the $\mathrm{GBC}$ rail project in terms of location, production capacities and environmental conditions make the $G B C$ rail one of the few projects of its kind. PTFI requires for its operations very specific equipment that many times must be custom-built (e.g. mine load centres for chute operations).

Many components of the GBC rail project are long lead-time equipment that requires completion of the plans for the expanding rail system well in advance. The GBC rail project lead times for some major components can take up to 1.5 years from the time the purchasing decision is made. The main long lead-time components of the project are; mine load centres (MLCs), train controls e-houses, and traction supply stations or rectifiers (TSS).

\section{$5.2 \quad$ Logistics}

Many components of the system are received by PTFI overseas and need to be shipped to the site using a transport method optimized for cost and delivery. PTFI has a dedicated team that provides support to PTFI in the global supply chain, purchasing and warehousing processes. PTFI's main entrance for deliveries is the Amamapare Port, located in the Lowlands of Papua, Indonesia. A secondary entrance for deliveries is the Mozes Kilangin International Airport located in Timika, Papua, in the lowlands about $60 \mathrm{~km}$ from the mine site.

Materials tracking is another major challenge of GBC rail project. Although PTFI requires vendors to deliver their products complying with strict packaging specifications, the project team must make sure that the vendor has accurately understood and applied the purchase order specifications. The logistics lifeline to a remote site can be four months or more; receiving just one wrong part can impact the entire project schedule and put the ability to manage the production expansion requirements at risk.

Another source of logistical challenges is the process of transporting every shipment to the mines and processing plant from lowlands to the highlands. More than 100 containers per day travel the 72-mile gravel road to support the overall mining operations. Scheduling and tracking of the specific containers for a particular project such as GBC Rail requires a diligent effort to manage.

\subsection{Site materials management}

The PTFI mine site is very remotely located in a mountainous area and storage space availability is minimal. Packages shipped to the mine and containers are individually bar-coded and site materials management team has to ensure that the containers are located in a logical way related to the construction team requirements. Storing materials in such way sometimes result in lost or damaged equipment, therefore in schedule delays.

The GBC rail project requires very specific materials (e.g. high-voltage cables) that are usually delivered in bulk and needs to be stored in the highlands during the construction process. Multiple storage locations and the high amount of rainfall in the highlands increase the risk of losing or damaging materials. GBC rail electrical and automation team has requested to the global supply chain team and Stantec Engineering to provide procurement support of electrical and instrumentation material. This strategy aims to facilitate communications between vendors and the site team, improve the decision-making process of technical and commercial bid reviews, and stagger delivery of dedicated containers to optimize the access to the materials being delivered in the highlands.

\section{$5.4 \quad$ Operating practices}

A top priority for PTFI and project collaborators is the safety of the people working in different scopes of the project. The GBC rail project is unique to PTFI and to the country of Indonesia, so many construction 
and operating methodologies are entirely new for most of the project workers. During the commissioning stage, safety has become a key for success because a new and complex system is being implemented. Procedures are being written and constantly updated to capture the operational risks of train operations and the associated mitigation plans.

The implementation of a new system as complex as rail automation requires a comprehensive set of new knowledge and skills needed by project workers. The implementation of procedures and worker training has become crucial for the cultural change product of the new operations since workers and collaborators need to be able to navigate in this new scenario with driverless equipment and restricted circulation areas.

Remote-loading operations is another source of challenges during this training and practice period. Loading an 11-car train requires a different set of skills compared to truck or scoop loading. PTFI has made remote-loading a priority, providing chute operators with the training and skills to improve loading efficiency to reach targeted train productivities. PTFI keeps in regular communication with LKAB-Kiruna in Sweden, which has a similar rail haulage system, in order to improve current remote-loading techniques and other operating practices.

Train operations are working 24/7 now. Based on June 2020 data, current physical availability reaches $97 \%$ with a utilization of $75 \%$. The top failure explaining downtimes in the system is lost communication between the locomotives and the train control system that causes the trains to halt activities. PTFI and Midroc are currently working on this issue, implementing new Wi-Fi spots along the rail track to minimize the communication issues.

Other sources of standby times are ore bin full and empty chutes, which are expected to be better resolved after crusher commissioning and while GBC is ramping up production and providing progressively larger tonnages.

During the design phase, the train travel speeds within the chute galleries and the unloading stations are set at $2.5 \mathrm{~km} / \mathrm{hr}$ for safety and loading efficiency. During commissioning, rail simulations and site team experience are proving that this speed is adequate in short chute galleries but becomes a cycle time bottleneck when chute galleries have more than six chutes. PTFI is studying updates in the train control system to allow for faster speeds ( $5 \mathrm{~km} / \mathrm{hr}$ ) within the chute galleries.

Wet muck handling is a situation that must be planned for given the high rainfall in the district and the experience at the operating DOZ mine. Rail haulage of wet muck is an operational condition that is undoubtedly expected in the future. The combination of introduced water into the ore column, along with finer material as the draw columns mature, will produce the wet ore condition that could spill from the drawpoint, loading chutes and unloading stations.

The issues begin on the extraction level and safety is managed there through the use of remotely operated loaders. On the haulage level, wet muck spills through the chutes and into the train, which will at times make loading the trains difficult. Studies are ongoing to develop modifications of the loading chutes and also the ore cars that can better manage wet muck conditions. But despite that, wet muck spills are expected to inevitably occur on the haulage level. The challenge then becomes how to quickly clean up the chute gallery when the spills occur so as not to delay production. Any solution would need a remote-control capacity because operators are not allowed to pass under a loading chute in a wet muck condition. Solutions include small bobcat loaders that push the wet material to $1.0 \mathrm{~m}$ diameter waste passes at the end of the chute gallery. A large rail-mounted vacuum unit is also considered to quickly clean the track, load the material onto ore cars and deliver the material to the unloading station. This aspect of the operation is an ongoing process to optimize how to handle the wet muck situations when they occur.

The currently installed track does not yet include the "loops" that will allow one-way traffic along the main lines and into the chute galleries (Figure 5). Completion of these loops is a high priority and is required to be able to continue the ramp-up to higher production levels. PTFI is working on efficiency plans 
allowing the development and installation crews to prioritize the rail loops development and improved track installation rates. Delays to implement the rail loop connections are a risk to the production plan because until the full loops are in place, the trains must reverse back into the chute galleries from the main rail lines.

\subsection{Haulage level and rail maintenance}

The GBC rail system is comprised of complex mechanical and electrical systems; it is also installed in a very difficult environment with potential geomechanical, hydrological and chemical risks. In order to have reliable and safe operations, the rail equipment and surroundings must be kept in the best working conditions with regular maintenance of rolling stock and railway, wayside equipment and tunnel conditions.

As the large cave fronts expand, the abutment stress is expected to impact the excavation surrounding the cave front. Rock strain will impact the GBC haulage level inducing floor heave, and also rib and back damage. Some design modifications have been implemented, such as expanding the pillars between the main rail lines and the chute galleries to help mitigate the damage from the cave stresses. Some other mitigation measures adopted are adjustments to the excavation profiles and ground support revisions. Monitoring and prompt repair is critical where full mitigation is not possible.

Another aspect of the PTFI underground mines is the high amount of water permeating into the excavations and operating under potential wet-muck hazard conditions. Hydrology models show that during certain events (such as storms), potentially $32,000 \mathrm{gpm}(2,150 \mathrm{lps})$ of water is expected to permeate into the GBC cave. Most of the water is directed to the drainage level, but in sectors where drain holes are not sufficient or vertical excavations are present, water could potentially flow through ore passes and ventilation raises creating a risk to the lower operating levels. The GBC cave has not yet experienced wet-muck events as the cave is in an early stage, but wet-muck handling is expected in the future and must be managed.

Corrosion issues are already an ongoing challenge at the GBC mine. The presence of sulphide minerals (pyrite) in significant percentages when mixed with water are creating acidic conditions in some sections of the rail system, presenting corrosion concerns of steel infrastructure, specifically ground support, chute steel and the railway. Corrosion damage can already be observed in some sectors of the GBC rail. Rail corrosion will increase the rail wear that would be expected from normal rail traffic conditions. PTFI is implementing the use of appropriate maintenance equipment such as a rail-grinding vehicle that would benefit the train operations by reducing the rail and rolling stock wear, noise and speed restrictions; it would also extend the rail life significantly. Currently, rail profiles are being monitored and inspected visually, and some protective measures are being implemented as specialized anti-corrosion paint in chute and steel infrastructure.

\subsection{Data analysis}

Data analysis is the process of evaluating data using analytical and statistical tools with the objective of extracting and interpreting useful information and supporting in the decision-making process. At the moment, there are multiple systems installed in GBC collecting data and information in real time. These systems include LHD operating reporting (MineGem), geotechnical and operations monitoring, GBC rail distribution control system and others.

Some of the challenges that PTFI, and most corporations worldwide face, is the ability to make this huge amount of data useful. In general, these challenges are related to the need of synchronizing different data sources, the shortage of skilled data analysts with mining experience, the ability to correctly understand and apply the results from the data analysed, and the ability to store and share big amounts of data in a remote location.

PTFI and Midroc Automation are working to provide the train control software with the ability to report maintenance and performance data from the locomotive computers and the INTERFLO system, including additional critical information from weight scales and axle bearing temperatures. The challenge is to 
manage that time-sensitive data in order to obtain the contained value to continuously improve the operating performance.

\section{$6 \quad$ Lessons learned}

After these initial years of project engineering, construction and implementation, there are multiple knowledge and understanding sources based on experience that should be taken into account as the operation expands (Table 2). The challenge is to continue to utilize these lessons learned, and work towards continual improvement in the installation and operation of the rail haulage system.

Table 2 GBC rail project lessons learned

\begin{tabular}{|c|c|c|}
\hline Category & Description & Mitigation measure \\
\hline Procurement & $\begin{array}{l}\text { Long lead-times can take up to } \\
1.5 \text { years since the purchasing } \\
\text { decision has been taken }\end{array}$ & $\begin{array}{l}\text { Monitoring of mine plans changes and evaluate } \\
\text { impact to procurement schedule }\end{array}$ \\
\hline Logistics & $\begin{array}{l}\text { Materials tracking during } \\
\text { shipping and storage at } \\
\text { Highlands }\end{array}$ & $\begin{array}{l}\text { Procurement support to site team staggering } \\
\text { dedicated containers delivered to the project }\end{array}$ \\
\hline $\begin{array}{l}\text { Site Materials } \\
\text { Management }\end{array}$ & $\begin{array}{l}\text { Risk of losing or damaging } \\
\text { materials while in PTFI storage }\end{array}$ & $\begin{array}{l}\text { Procurement support to site team staggering } \\
\text { dedicated containers delivered to the project }\end{array}$ \\
\hline \multirow[t]{5}{*}{$\begin{array}{l}\text { Operating } \\
\text { Practices }\end{array}$} & $\begin{array}{l}\text { Implementation of a new system } \\
\text { within PTFI experience creates } \\
\text { safety and skills concerns }\end{array}$ & $\begin{array}{c}\text { Training sessions for management and operators } \\
\text { Procedures are in constant revision and are } \\
\text { regularly updated }\end{array}$ \\
\hline & $\begin{array}{l}\text { Remote-loading of } 11 \text {-car trains } \\
\text { requires a new set of skills and } \\
\text { can be improved }\end{array}$ & $\begin{array}{l}\text { Training and operations are closely monitored. } \\
\text { Others experience is also studied }\end{array}$ \\
\hline & $\begin{array}{l}\text { Lost communication has become } \\
\text { train system's top failure }\end{array}$ & $\begin{array}{l}\text { Wi-Fi coverage within the haulage level is } \\
\text { constantly reviewed and improved }\end{array}$ \\
\hline & $\begin{array}{l}\text { Train speed of } 2.5 \mathrm{~km} / \mathrm{hr} \text { within } \\
\text { chute galleries is inefficient and } \\
\text { affects train productivity }\end{array}$ & $\begin{array}{l}\text { PTFI and Midroc are working on increasing chute } \\
\text { galleries maximum speed to } 5 \mathrm{~km} / \mathrm{hr}\end{array}$ \\
\hline & $\begin{array}{l}\text { Inability to connect track loops is } \\
\text { a risk to the production plan as } \\
\text { train traffic increases }\end{array}$ & $\begin{array}{l}\text { PTFI is working on prioritizing loop connectivity } \\
\text { and constantly improving the life-of-mine design }\end{array}$ \\
\hline \multirow{3}{*}{$\begin{array}{l}\text { Haulage } \\
\text { Level and Rail } \\
\text { Maintenance }\end{array}$} & \multirow[t]{3}{*}{$\begin{array}{l}\text { Abutment stress will impact the } \\
\text { GBC rail inducing damage }\end{array}$} & $\begin{array}{l}\text { Updated pillars size (CG41 and CG42) and chute } \\
\text { gallery location (CG31 and CG32) }\end{array}$ \\
\hline & & $\begin{array}{l}\text { Adjustments to the excavations profiles and } \\
\text { ground support }\end{array}$ \\
\hline & & Monitoring plan will be implemented \\
\hline & \multirow{2}{*}{$\begin{array}{c}\text { Water permeability and } \\
\text { corrosion difficult operations } \\
\text { deteriorating railways, steel } \\
\text { infrastructure and ground } \\
\text { support }\end{array}$} & $\begin{array}{l}\text { Drainage plan have been implemented and } \\
\text { modelling is constantly reviewed }\end{array}$ \\
\hline & & $\begin{array}{l}\text { Railways are constantly monitored. Anti-corrosion } \\
\text { paint is being used in steel infrastructure }\end{array}$ \\
\hline
\end{tabular}


Table 2 GBC rail project lessons learned, continued

\begin{tabular}{|c|c|c|}
\hline Category & Description & Mitigation measure \\
\hline Data & Distributed control system (DCS) provides & Trains control software will be able to report \\
Analysis & raw-data from locomotives and INTERFLO & maintenance and performance data \\
\hline
\end{tabular}

\section{$7 \quad$ Conclusions}

The GBC rail haulage system is a complex multi-disciplinary project developed to support the operations of the GBC mine at peak production rates of 130,000 to 160,000 tpd. The GBC rail project team is implementing one of the largest and most sophisticated automated underground rail haulage operations in the world.

The ability to successfully implement a project of this magnitude comes with the responsibility of preparing the project teams for the mining footprint and tonnage expansions. PTFI has developed a process to capture changes in the production and development plans and to anticipate changes in the engineering and procurement efforts of long lead-time equipment. This schedule defines the strategy required to achieve the critical commissioning dates to continue the GBC production ramp-up. Engineering and procurements efforts have also been scheduled sequentially to optimize the utilization of resources internally and from PTFI providers.

Several challenges, risks and mitigation measures have been presented in this paper. The most important challenges are related with the procurement efficiency of specialized equipment and train controls; the logistics of delivering the right materials and equipment to the construction crews at the right time; the management of materials on site to avoid damage and losses; improvements needed in the different operating practices, infrastructure and rail maintenance combined with environmental disadvantages; and the preparation of management and technical teams to make intelligent use of data analysis tools. Mitigation measures are focused on anticipating the problems by incorporating the knowledge of the surrounding rock, monitoring, and constant improvement of operations and maintenance procedures. The key to the success of the GBC rail haulage system is to manage all of these challenges in an efficient way so that the production targets can ultimately be achieved.

\section{References}

Hariyadi, A, Castro, M \& Fisher, J 2016, 'Automated Train Ore Transport', in C Carr \& G Chitombo (eds), Proceedings of MassMin 2016, The Australasian Institute of Mining and Metallurgy, Sydney, pp. 563-569.

Pascoe, N, Mead, B \& Vega, H 2016, 'Grasberg Block Cave Haulage Project - Design and Construction Update', in C Carr \& G Chitombo (eds), Proceedings of MassMin 2016, The Australasian Institute of Mining and Metallurgy, Sydney, pp. 585597. 